\title{
PROBATION AND PAROLE AS ELEMENTS IN CRIME PREVENTION
}

\author{
SANPORD BATES*
}

As Justin Miller has said, "The battle against crime is a battle on many fronts." Along with the persistent campaign of the federal government to wipe out the gangster and the desperado there is being undertaken a quiet but efficient campaign to improve the operation of the probation and parole systems. This is a problem of vital importance to our communities.

\section{Probation}

I.

Probation is first of all an attempt to reconstruct a potential offender, a first offender, a man who after examination by competent scientists is determined to be susceptible of reconstruction. It is aimed at the individual and not at his crime. It may be regarded, I think, as an investment by the community in humanity. Any correctional process which saves a man from a life of crime without visiting upon him the stigma of a prison commitment is a valuable process and is in the interest of protection. It is financially economical from three points of view. It may enable him to make restitution to the wronged party. It enables him to pay the fine through keeping him on probation while the fine is being paid, instead of sending him to jail where he cannot pay. It saves the state or federal government the cost of his board in prison, which is a very material item.

It is an aid rather than a hindrance in the administration of justice because it opens to the court the facts about the man's past life, about his possibilities, about his industrial ability, and enables the court to give a much surer and more accurate judgment, and many times an authentic investigation by a probation officer results in a man receiving a sentence who otherwise might escape one, just as often in the name of humanity it postpones or eliminates a sentence of the man who can be more surely reconstructed by that method.

It has been proven over and over again that probation wisely administered is a deterrent. Here are the two opportunities originally open to the court: A man if found guilty must either be let go or be sent to prison. When those were the only

- LL.B. Director, Bureau of Prisons of the United States, since 1930; Superintendent of Federal Prisons, 1929-1930; Commissioner, Massachusetts Department of Correction, 1919-1929. President, American Prison Association, 1926. Member, Mass. Bar. Author of numerous articles on penological problems. 
alternatives, it is doubtless the fact that many men were not arrested, that many men were not tried, that many men were not subjected to any disciplinary treatment, because of a feeling in the minds of the police, the prosecutor, or the court that it was unfair to interrupt a man's career, to damage his life by using the only method available, namely, sending him to prison.

With the realization of the wide range of acts which constitute criminal activities, that some conduct which is labeled criminal involves no very great moral turpitude, and with the further realization of the tremendous variation in personalities which come before our courts of justice, it would indeed be unthinkable if there were not some alternative to imprisonment, an alternative which would not turn the culprit free but would retain a measure of control and guidance for his benefit and the protection of society.

So I like to think of probation as an alternative to letting a man go free without restraint, without guidance, and without any hope of reconstruction, and not emphasized, as it is so often emphasized by the public, as an avoidance of prison or as an expression of leniency. Properly administered, probation is a deterrent, it is a restraint, it is a compulsion upon a man to do what he can to reëstablish himself.

2.

A critical evaluation is a process that many of us would like to avoid, if possible. One of the hopeful signs of the times, however, is the growing realization, even by social workers, that if their accepted practices are to survive and their preconceived notions are to continue to have validity, they must be submitted to the searching light of research and be tested by their actual results.

Such a process is comparatively easy in the commercial field. It is not particularly difficult in some of the more scientific activities of the present day. Our medical men have devised mortality tables. They know the probable percentage of success of certain operations. They have tested the value of certain treatments.

When one sets out, however, to evaluate social processes, some of the inherent difficulties soon become apparent. In spite of the many discoveries in the realm of psychiatry, psychoanalysis, and behaviorism, we are still a long way from being able to apply an accurate yardstick to the problem of human conduct and delinquency. There are too many variable factors present. The Gluecks in Massachusetts, ${ }^{1}$ Vold in Wisconsin, ${ }^{2}$ and Burgess in Illinois ${ }^{3}$ have attempted to set up devices for prediction whereby the conduct of individuals can be forecast. Within certain limits this may be done, but the human soul or personality is not yet ready to submit itself to any set of rules and regulations. And so, while one may be justified in making generalizations in the field of agriculture, commerce, or medicine, one hesitates to

${ }^{2}$ Sce S. G. \& E. T. Glueck, 500 Criminat Careers (i930) c. xvi.

${ }^{2}$ See Vold, Prediction Methods and Parole (1931).

${ }^{3}$ See Burgess, Factors Determining Success or Failure on Parole, Irt. Crime Survey, c. xi, pt. D, pp. 516-540; Bruce, Harno, Burgess and Landesco, Workings of the Indeterminate Sentence Lat' and the Parole System in Illinors (Ig28) c. xxx. 
predict what a given individual will do under a certain set of circumstances or what effect upon that personality certain treatment or discipline may have, simply because certain reactions have developed in other similar cases.

Is there any way by which the efficacy of probational treatment may be tested? Probably we are not ready yet to affirm that in all cases probation should be substituted for imprisonment or other harsher forms of punishment. Can we devise a set of guide posts whereby, based upon our experience of 50 years, we can direct the course of correctional treatment in the future? In what types of cases, with what personalities and under which kinds of procedure does probational treatment ordinarily succeed? When and to what extent must we abjure the use of probation in favor of imprisonment?

I shall have to content myself with referring briefly to a few of the attempts at the evaluation of probation that have come to my attention. One reason why we cannot present more evidence is that probation has developed on a more or less isolated basis. Every probation officer has a rough idea of the percentage of his successes, but he rarely follows his cases after the termination of their probationary term. Unfortunately, there are few states in which there is an effective state control and in most of these the type of information preserved contains very little more information than a statement of the number of probationers revoked. Some day the insistence of the National Probation Association upon the necessity for supervision and accurate record keeping will prevail.

3.

In 1922 Herbert Parsons was ordered by the Massachusetts Legislature to find out what had become of the people who had once been on probation, and he proceeded to compile one of the very few authoritative evaluations of probation. Roughly speaking, he determined that 78 per cent of those taken on probation in a certain selected group or community could be called successes. One may compare this with the Glueck ${ }^{4}$ study in the same state which contended that 60 per cent of the men sent to the State Reformatory must be classed as failures.

Mr. Parsons' study, as I recall it, went somewhat further and stated that out of the number of cases who had successfully completed their probation period he could only discover four out of every hundre! who had later on run afoul of the law.

In Baltimore in 1932 a study of the subsequent conduct of persons released on probation was undertaken by officials of the Baltimore Crime Commission, ${ }^{5}$ who might be said to be not particularly friendly toward the idea of probation. This inquiry shows that of 288 cases released in care of the probation department 22 per cent were arrested while on probation. Of the 26 who were released to someone other than the probation department 27 per cent were arrested while on probation, and of the 159 cases who were released on probation without supervision, I9 per cent

\footnotetext{
Supra note $\mathrm{r}$.
}

From unpublished data furnished by the Baltimore Criminal Justice Commission. 
were arrested while on probation. I doubt if this evidence can be taken as showing that men without supervision behave better than those with it. I assume that those released without supervision were a superior class of risk.

The United States Probation System ${ }^{6}$ has but recently been provided with sufficient funds to secure reasonably necessary supervision. At the beginning of the fiscal year 1933, there were 23,200 persons on probation under the supervision of the United States probation officers; 17,024 were placed on probation during that year, leaving the total number handled, 39,986, and the number under supervision at the end of the year, 30,967 . During that same year there were $\mathrm{I}, \mathrm{I} 58$ revocations of probation. If one is considering the total terminations of probation, this amounts to II.I6 per cent, but if the percentage is based upon the total number handled, it amounts to 2.9 per cent.

Would these same individuals have succeeded in the same proportion if they had been sent to the reformatory? Would they have had as much success if they had had no probation supervision whatever? The most that we can say is that there is less recidivism among probationers than there is among ex-prisoners.

It occurs to me that there is another legitimate method of evaluating the success of probation. That is, by comparing the results in a rather general way from one state to another. I do not think I shall find any dissent from the statement that probation has developed to a greater extent in Massachusetts than in any other state in the country. I should not hesitate to put New York second. States like Wisconsin, Minnesota, Indiana, and New Jersey come after. We know, of course, that many of the southern and western states have no organized or systernatic probation at all. For years Massachusetts has averaged four times as many people on probation as in prison. The number on probation in New York at the present time substantially exceeds those who are in correctional institutions. The latest report of the Bureau of the Census ${ }^{7}$ shows that the average for the whole country of the number of persons per 100,000 committed to state prisons and reformatories in 1932 is 70.2. This figure for Massachusetts is 35.8 and for New York is 37.5 .

One might say that this is not surprising, because if people are put on probation they naturally aren't put in prison. I have attempted to supplement these data by reference to the number of crimes committed. The last issue of the publication of the United States Division of Investigation, "Uniform Crime Reports," gives the rate per 100,000 of offenses known to the police for the period from January I to June $30,1933 .^{\circ}$ I have taken the crime of robbery as a typical offense in which the public is interested from the point of view of protection.

'The United States Probation System was established by the Act of March 4, 1925, 43 StAт. 1259, 18 U. S. C. A. $\$ \$ 724-727$, but no judge was permitted to appoint more than one salaried probation officer. This restriction was removed by amendment in June, r930. 46 STAT. 503, 18 U. S. C. A. (Supp. 1933) $\$ 726$.

${ }^{7}$ U. S. Bureau of the Census, Prisoners in State and Federal Prisons and Reformatories, y93i AND 1932, p. 4. (Ratios based on general population 15 years old and over.)

${ }_{4} 4$ UNIform CRIMe Rep. No. 2, 9-10 (1933). 
I find that the figures range from 46.7 per roo,000 in the South Atlantic States to 89.5, in the East North Central States, whereas, in Massachusetts, the figure is xo.4, and for New York it is 9.2. The figures for larceny and theft vary from 331.8 in the East South Central States to 621.4 in the Pacific States, while in Massachusetts there were 197.6 per 100,000 and in New York, 177.I.

These figures may not be convincing, but at least they have a tendency to offset any claim that the liberal use of probation is accompanied by any increased amount of crime.

\section{Parole}

I.

When a prisoner emerges from the prison after a period of enforced discipline, abnormal restraint and deteriorating confinement what is likely to be his frame of mind? Can he readily be assimilated in our competitive industrial life? Will he find the friendly counsel and assistance necessary to bridge over this difficult period in his career? Will the new resolutions that he has made during the long days and nights in prison remain with him as he faces the unbridled temptations of our urban communities? Will he, after several futile attempts to stand firm, gravitate to the level of the street-corner gang or to those semi-criminal types which may constitute the only friends and resources he has?

What is the duty of society toward him? If something is not done of a constructive nature, will he not become more of a potential menace to the peace and safety of his neighborhood than before he was sentenced?

The penological device known as parole is modern society's solution of this problem.

2.

Ever since prisons were devised as places of punishment 150 years ago the menace of the discharged prisoner has been recognized. Many interesting experiments have been made. In the early days deportation was relied upon to take care of the discharged prisoners, and we find references to a procedure similar to our present-day parole in the record of Commander Phillip as Governor of New South Wales in 1790. To certain English convicts transported to Australia the Governor was permitted to make remission of part of their sentences as an incentive to hard work. Many conditionally released prisoners found opportunity in the sheep industry in that far continent.

Later, under the leadership of Captain Alexander Machonochie in 1840 , the Australian system became the true forerunner of the system of conditional liberation, or parole, as we now know it. It was developed by Sir Walter Crofton of Ireland and originally applied only to convicts shipped to Australia; but in 1853 , under the Ticket of Leave Act, ${ }^{9}$ it was applied to convicts on English soil.

${ }^{2} 16 \& 17$ VICT. c. $99 \$ 9$ (1853). 
A book entitled "Purgatory for Prisoners," by the Rev. Aubrey Shipley, published in 1857 , describes the almost unbelievable success which attended the adoption of the indeterminate penal establishments in Ireland, to which discharged convicts were sent from prison, preparatory to their final discharge into the community.

The necessity for some kind of incentive for men in prison was early recognized, and many of the so-called "good time" laws adopted by the various states of America date from the first and second decades of the nineteenth century. These were quite different, however, from the parole laws; the latter began to be developed only with the recognition of the wisdom of the indeterminate sentence.

$3 \cdot$

Parole as now administered in our most progressive states is the conditional liberation of a prisoner at a time to be decided by a board, or commission as the time most advisable for him and the community. Instead of a definite sentence from which the prisoner may earn no deduction and toward which he must look without preparation or modification of his conduct, there is provided an adjustable date toward which he can work. This date can be advanced if his conduct and prospects justify it, or it can be delayed if his lack of progress and the interest of society warrant.

It is of prime importance that the discharged convict shall be provided with a suitable home and a job sufficient to keep him from want and temptation and that he be released under such circumstances as will induce his obedience to the laws. These concomitant factors to release can be insisted upon under the parole system, but not under the definite discharge plan.

Again, everything depends upon the mental attitude of the discharged prisoner. If he comes out at the end of a stated period, it is almost inevitable that he should have the feeling that he has paid his bill in full, that he and society are square. $\mathrm{He}$ might even feel that he had somewhat overpaid his debt and would have no compunction about evening it up at the first opportunity.

An adjustable parole system, however, may be so devised that the compulsion can be placed upon the prisoner himself. He has not been handed a one-way ticket to freedom. He has been allowed to go out on his parole-on his word of honor, so to speak-and, if and when he fails, he may be returned without the delay of a formal trial by jury.

The wise penologist today admits that the fundamental purpose of all penal systems is the protection of the public. Tested by this requirement, which is the safer method of discharge for convicts of all classes, of all degrees of criminality and all types of personalities: to be turned out free from prison without let or hindrance, without the guidance or restraint of personal or official supervision, or to be returned to the community under close control?

Much discussion has been had from time to time as to the type of person who should be released under parole, whether parole should be confined to first offenders 
or hopeful cases and whether it should be denied to certain classes of prisoners. The sound practice would seem to be that the protection of the public demands that every prisoner who emerges from a prison or reformatory should come out under supervision for a greater or less period.

This same protection of the public will undoubtedly demand that some dangerous men who give no prospect of reform should never be released from an institution. With that principle most penologists have no quarrel; but 95 per cent of all prisoners must be released at some time, and when they do emerge it is much safer to have them on parole than otherwise.

\section{4 .}

In the public mind the idea of parole, however, is inextricably confused with leniency. To many, the release of a prisoner on parole means that he has not been kept in prison long enough. Now, this may or may not be true. There is no evidence to show that, by and large, criminals of one class or another spend any less time in prison before being released on parole than if they had been sent there under a definite sentence.

A study made in Massachusetts some years ago indicated that the average time served in prison under the parole system was slightly longer than the time served when definite sentences were the rule. Quite recently these Massachusetts figures have been checked more carefully. In 1895, which was the last year of the definite sentence system, 186 prisoners were released. Their cases were compared with those of 200 prisoners released in 1925 under the Massachusetts parole system, and it was found that the average time served before the release on the definite sentence was 4.65 years, whereas the average time served before the first release under the parole law was 4.95 years. All the time served on parole and all the time served in prison in cases where parole was later revoked should be added to the amount of time served in the first instance.

Naturally, the public becomes indignant when it learns that a crime is committed by a prisoner released on parole. There is no assurance, of course, that the same crime would not have been committed if the same prisoner had been released by the less scientific and less safe method of absolute discharge. We might not think to blame the court in the latter instance for not requiring that the prisoner serve a longer time in prison, but we do not hesitate to blame the parole board members if, in the exercise of their judgment, they do not hold the paroled prisoner to the ultimate length of his sentence.

\section{$5 \cdot$}

The ideal parole system would give considerable latitude to the board of parole within certain stated limits. The court could indicate within those limits what it thought the punishment should be. There should be a minimum time in advance of which no release could be accomplished. There should be likewise a maximum limit on the time to be served in prison, even beyond which the prisoner must stay 
on parole for a considerable period. This policy has been followed since 1932 in the prisons of the federal government. ${ }^{10}$ No prisoner can be paroled earlier than one-third of his sentence, but when his minimum sentence (that is, his maximum sentence less the statutory commutation for good conduct) is finished and he has not been paroled, he must go out under parole conditions to serve until the end of his maximum time.

Parole boards, in common with police, district attorneys, judges and psychiatrists, make mistakes. Their mistakes are highly advertised. Those prisoners who become parole successes, however, are protected in their anonymity and in most jurisdictions their number goes far to offset the few mistakes that parole boards make. With the advice of skilled psychiatrists and sociologists, with parole boards amply paid and free from political control, these mistakes can be reduced to a minimum. The parole board should be left free to work toward a realization of the ideal which would keep every man in prison up to the point when it was wise for him and safe for the public that he be released, and not one day beyond this point.

Given a system under which convicts receive ample and constructive punishment -punishment which prepares them for life on the outside and does not disable them for the resumption of normal activities-it is not difficult to proclaim that every such sentence should be followed by a period of supervised guidance, which we know as parole.

\section{Federal Probation and Parole Administration}

I.

The federal government in the establishment and development of its probation system has made two noteworthy accomplishments. Owing to the fact that the system of federal probation, the management of the penal institutions and the supervision of all paroled federal prisoners come under one bureau, it has been possible to arrange for a continuity of treatment of a given individual. The routine duty of a probation officer has been broadened until he now acts in four separate but related capacities:

(I) $\mathrm{He}$ is the social investigator and adviser for the court.

(2) $\mathrm{He}$ is the best friend and supervisor of such offenders as may be placed in his charge on probation.

(3) He forwards to the penal institution with such of his charges as receive commitment thereto the result of his social investigation and his suggestions for institutional treatment.

(4) On the ultimate discharge from the institution of the prisoner on parole he resumes the guidance and control of the man with whose case he has already become familiar.

In the last analysis there is no fundamental difference in the technique used as the basis of probation supervision and parole supervision. While in the federal

${ }^{10} 47$ STAT. 381 (1932), I8 U. S. C. A. (Supp. 1933) \$\$716a, 7x6b. 
government we have thought it wise to provide for every paroled man a first friend or parole adviser, properly vouched for by a recognized local social agency, we have not hesitated to combine the work of official parole supervisor with that carried on by the probation officer and we submit for the consideration of those who are anxious to work out an economic and continuous system for the care of delinquents the desirability of this plan.

The second important contribution which I think our federal officers have made is the handling of the relatively small number of juvenile delinquents coming into the federal penal system. Three years ago we embarked upon a campaign to eliminate juveniles from our institutions. It will immediately be seen that in practically every state of the country the definition of juvenile delinquency is such that even though a boy may have been technically guilty of a federal offense, he is likewise the subject for the attention of some local juvenile court. Following a recommendation by Congress that the care of juvenile delinquents was a state matter, it has been the aim of our probation officers, wherever possible, to induce the federal district attorneys to turn over to the local or state juvenile courts and juvenile officers the care of such boys and girls as might heretofore have come into our system. The success with which this has been accomplished may be measured by the fact that the number of boys sent from distant points to the National Training School for Boys in Washington has decreased from 473 on July 1 , I930, to 90 at the present time.

\section{2.}

If the probation officers of the country are to accept the broader rôle of activity which some of these observations suggest, all the more important does it become that they should be carefully selected and wisely trained. The federal government has undertaken to set up training stations for the newer probation officers in one or two of its offices, notably that in New York City. A noticeable tendency is marked in many of the states to professionalize the personnel in a similar fashion.

The adoption by Congress of the law ${ }^{11}$ authorizing groups of states to enter into compacts for the more efficient warfare against crime presents an opportunity to increase the effectiveness and the protective features of our state probation and parole systems. Such compacts may be useful in two directions. First, they could set up a much simpler and a more prompt functioning system of interstate rendition. It has been repeatedly shown in recent months that the modern criminal is possessed of much greater mobility than those of a bygone era. State lines mean little or nothing to the Dillingers of today and artificial barriers must not be permitted to handicap the prompt operation of our criminal laws.

In the second place, reciprocal agreements may be made under such compacts by states for the better supervision and control of persons released on parole in one state to work and live in another. The Department of Justice approves the efforts

II Public, No. 293, 73rd Cong., 2nd Sess. (1934), I8 U. S. C. A. (Supp. 1934) \$420, discussed in Dean, The Interstate Compact-A Device for Crime Repression, supra p. 460. 
now being made to utilize the opportunity offered under this new federal criminal statute to facilitate joint or concerted action by state governments.

The duty of the present moment with reference to parole is to put more intelligence, more backbone and more honesty into its operation. When this is done we shall recognize parole as an integral and necessary part of any penal system. We shall discontinue our criticisms of it as a method and demand the improvement of its administration. 